\title{
Preference of Entrepreneurship among Under Graduate Engineering Students - An Analysis
}

\author{
B. Mallesu ${ }^{1}$, RRN Chowdary ${ }^{2}$ \\ ${ }^{1}$ Department of Management Studies, Hyderabad Institute of Technology and Management, Hyderabad \\ ${ }^{2}$ Department of Mechanical Engineering, Hyderabad Institute of Technology and Management, Hyderabad \\ 1dean.aid@hitam.org \\ 2rrnchowdyahoo.com
}

\begin{abstract}
The true transformation of Engineering Education happens with Innovation and Entrepreneurship. Today's Engineers have proved that they are innovative and successful Entrepreneurs. Engineering Education inputs are visible in many ways in terms of innovation of new technologies, products, processes, methods, idea. Innovation and entrepreneurship have changed the way of doing things. Conversion of innovation into marketable product undergoes many crucial stages with strong base in Technology, marketing and funding.
\end{abstract}

Keywords: Engineering, Innovation, Entrepreneurship, Investment, Family support, Risk bearing ability

\section{Introduction:}

Entrepreneurship is doing things differently that are generally not done in the regular course of businesses. In other words Entrepreneurship is completely a new initiative of a new idea and converting it into a new business. Entrepreneurship adds new business enterprises, employment and enhances GDP of the country.

All business men are not Entrepreneurs, because they do the same business differently with same products/services. But Entrepreneurs, innovate and introduce completely a new Product/Service/Model to the economy and take risks. Innovation and Entrepreneurship is not limited to their own business enterprises, today every business enterprise requires innovative and entrepreneurial skills from their employees. The standing examples are Mr. Satya Nadella CEO of Microsoft and Pichai Sundararajan CEO of Google.

Innovation generally refers to the creation of better ideas which are accepted by markets, governments, and society. Innovation follows invention, wherein the idea is transformed into a marketable product ${ }^{1}$.

\section{B. Mallesu}

Department of Management Studies, Hyderabad Institute of Technology and Management, Hyderabad dean.aid@hitam.org
Most of young engineers of today are more creative, innovative and enterprising with high aspirations. With this in view, a survey was conducted to obtain the preferences of the students and identify the problems thereof.

\section{Research Methodology}

A survey was undertaken to collect data from 252 students of third and final year of B.Tech in CSE, ECE, EEE and Mechanical Engineering braches in our college.

\section{Objectives of the study}

A. Interest in Innovation and Entrepreneurship among the Engineering students.

B. Choice of entry point of the respondents, Such as immediately after B.Tech without any work experience (or) with 5 years of work experience (or) with 10 years of work experience.

C. Whether their family supports them to become an Entrepreneur.

D. Whether they have Investment/Funding constraints.

E. To know their risk profile.

F. Whether their present Engineering education ignited them to pursue their career on Entrepreneurship.

G. Need of a dedicated center for Innovation and Entrepreneurship in their colleges.

4. Research Results:

A. For 252 students - overall:

- $67 \%$ of students have expressed that they want to be entrepreneurs.

- $25 \%$ of students expressed that they want to be entrepreneurs immediately after their B. Tech, 60\% after 5 years of work experience, $15 \%$ after 10 years of work experience. 
- $\quad 46 \%$ of them have an idea of Project in their mind.

- $59 \%$ of them have their family support.

- $68 \%$ of them have constraint for investment.

- $28 \%$ of them are High risk takers, $53 \%$ are Moderate risk takers, $3 \%$ are Low risk takers and $16 \%$ are not prepared to venture into entrepreneurship.

- $60 \%$ of them expressed their present Engineering education helps them to become entrepreneurs.

- $\quad 78 \%$ of them expressed that their college should have dedicated center for Innovation and Entrepreneurship (CIE).

B. For $67 \%$ (172 students) - Focused group:

- $35 \%$ of students expressed that they want to be Entrepreneurs immediately after their B. Tech, $58 \%$ of them after 5 years of work experience, $7 \%$ of them after 10 years of work experience.

- $55 \%$ of them have Ideation (idea)/Project in their mind.

- $69 \%$ of them have their family support.

- $73 \%$ of them have constraint of investment.

- $31 \%$ of them have High risk taking ability, $57 \%$ are of Moderate risk, $3 \%$ are of Low risk and $7 \%$ of them are risk averse.

- $\quad 65 \%$ of them expressed their present Engineering education helps them to become an Entrepreneur.

- $66 \%$ of them expressed that their colleges should have dedicated center for Innovation and Entrepreneurship.

C. For $33 \%$ ( 82 students) - Unprepared group:

- No student expressed that they want to be an Entrepreneur immediately after their B. Tech; but $30 \%$ of them after 5 years of work experience, $45 \%$ of them after 10 years of work experience preferred to be Entrepreneurs.

- $25 \%$ of them have Ideation (idea)/Project in their mind.

- $42 \%$ of them have their family support.

- $60 \%$ of them have constraint of investment.

- $25 \%$ of them have High risk taking ability, $41 \%$ of Moderate risk, $6 \%$ of them Low risk and $28 \%$ of them are risk averse.

- $\quad 72 \%$ of them expressed their present Engineering education helps them to become Entrepreneurs.

- $\quad 80 \%$ of them expressed that their colleges should have dedicated center for Innovation and Entrepreneurship.

Table 1 : Time Horizon for Entry into Entreprenuership

\begin{tabular}{|l|l|l|l|}
\hline Category & $\begin{array}{l}\text { After } \\
\text { B.Tech }\end{array}$ & $\begin{array}{l}\text { After 5 Years } \\
\text { Work } \\
\text { Experience }\end{array}$ & $\begin{array}{l}\text { After 10 } \\
\text { Years Work } \\
\text { Experience }\end{array}$ \\
\hline Overall & $25 \%$ & $65 \%$ & $15 \%$ \\
\hline Focused Group & $35 \%$ & $58 \%$ & $7 \%$ \\
\hline $\begin{array}{l}\text { Unprepared } \\
\text { Group }\end{array}$ & Nil & $30 \%$ & $45 \%$ \\
\hline
\end{tabular}

Table 2 Ideation (idea)/Project in their mind

\begin{tabular}{|l|l|}
\hline Category & Percentage \\
\hline Overall & 45 \\
\hline Focused Group & 65 \\
\hline
\end{tabular}

\begin{tabular}{|l|l|}
\hline Unprepared Group & 25 \\
\hline
\end{tabular}

Table 3 Family support

\begin{tabular}{|l|l|}
\hline Category & Percentage \\
\hline Overall & 59 \\
\hline Focused Group & 69 \\
\hline Unprepared Group & 42 \\
\hline
\end{tabular}

Table 4 Investment constraint

\begin{tabular}{|l|l|}
\hline Category & Percentage \\
\hline Overall & 68 \\
\hline Focused Group & 73 \\
\hline Unprepared Group & 60 \\
\hline
\end{tabular}

Table 5 Risk taking ability

\begin{tabular}{|l|l|l|l|l|}
\hline Category & High & Moderate & Low & NO \\
\hline Overall & 28 & 53 & 3 & 16 \\
\hline Focused Group & 31 & 57 & 5 & 7 \\
\hline Unprepared Group & 25 & 44 & 6 & 25 \\
\hline
\end{tabular}

Table 6: Relevance of Engineering education to Entreprenuership

\begin{tabular}{|l|l|}
\hline Category & Percentage \\
\hline Overall & 60 \\
\hline Focused Group & 65 \\
\hline Unprepared Group & 72 \\
\hline
\end{tabular}

Table 7: Need for dedicated center for Innovation and Entrepreneurship

\begin{tabular}{|l|l|}
\hline Category & Percentage \\
\hline Overall & 60 \\
\hline Focused Group & 65 \\
\hline Unprepared Group & 72 \\
\hline
\end{tabular}

All the above 7 factors are represented together in the form of Histogram for 3 groups as under:

- $\quad$ Group $\mathrm{O}=$ Overall (for 252 Students)

- Group A = Students intend to be Entrepreneurs (focused group -170 Students)

- Group B = Students who do not wish to be Entrepreneurs ( unprepared group 82 Students)

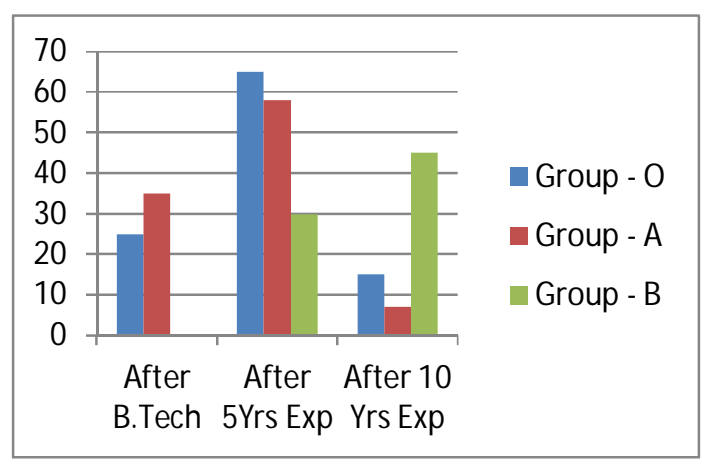

Time Horizon- Entry point into Entrepreneurship 

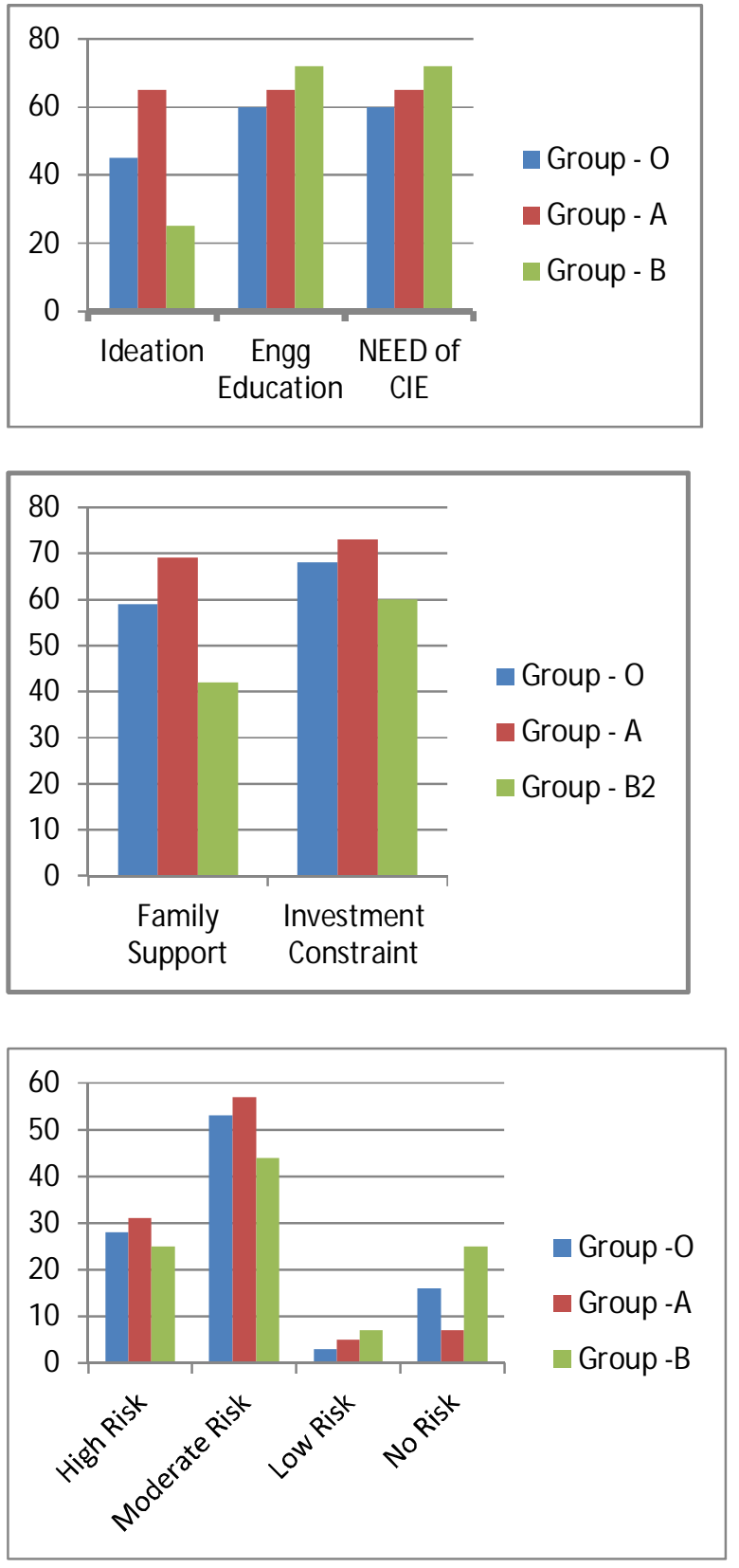

\section{Research Findings:}

Above survey data, reveals following trends:-

A. Focused group:

Nearly $1 / 3$ of respondents are well focused to be Entrepreneurs immediately after their graduation. This group has shown that $2 / 3$ of them have project idea in their mind, and equal number has their family support. However, only $1 / 3$ of them have high risk takers, because they felt that the funding support is difficult to comb by.

These students exhibit strong culture of discipline as pointed out by Jim Collins in his book titled "Good to Great"'. Wherein, the author brings out that these people are guided by thoughts of 'what they are good at'. They like to take their thought/idea to realm of action through Entrepreneurial ventures.

Considering the National priority of fostering entrepreneurship; a study on R\&D budget by USA, China and India spend of about $2.8 \%, 1.9 \%$ and $0.9 \%$ respectively from their GDPs. India has a long way to catch up with other two nations both in percentages and quantum of budget. While this may take decades, we can at least follow their process of funding R\&D projects to universities rather than depending on state run R\&D Labs. Private sector also could adapt this. This would lend impetus to Entrepreneurship ${ }^{3}$.

\section{B. Un prepared group:}

In this group $1 / 3$ of them prepared to be Entrepreneurs only after 5 years of work experience, but nearly $50 \%$ of them prepared to be Entrepreneurs after 10 years of work experience. This is due to the financial constraint of Entrepreneurship

In general, $50 \%$ of the entire sample of 252 felt that Entrepreneurship is an alternative to seeking employment. This 50\% also feels Engineering Education gives sound basis for Entrepreneurial venture, therefore recommends Center of Excellence for Innovation and Entrepreneurship in their college

\section{Recommendations for further studies:}

In view of Prime Minister's priorities such as 'Skill Development', 'Make in India' and 'Digital India', the central organizations such as ministry of HRD, AICTE and UGC should constitute a committee to introduce Entrepreneurship as a core subject in Engineering Education. A study on policy initiatives by Central and State governments to promote Entrepreneurship is required.

\section{Conclusions}

From the survey of Engineering students from this Institution, it emerges that $1 / 3$ are highly motivated to be Entrepreneurs immediately after their graduation. However, they need support from funding agencies, which is difficult with banks groaning heavily of their Non Performing Assets (NPAs). Unless reforms such as Banking laws, Labour reforms, Land acquisition and other enabling reforms come through, the take off may not be smooth.

For others $2 / 3$ of the respondents, it may take a decade to consider Entrepreneurship as an option

\section{References.}

1. Tarek M. Khalil (2000), Process of Innovation, in Knowledge and Technolog: key to Competitivensess and Wealth Creation, Mc Graw Hill International Editions, Singapore PP23. 
2. Jim Collins (2002), Culture of discipline, in "Good to Great”, Herper Collins Publications, New York, PP120 $-126$.

3. A Report in the Economist based on research by Mckinsey Global Institute and PWC as reported in the editorial column of Economic Times - Date: 24.04.15 